\title{
Attenuation of Staphylococcus Aureus By Pomegranate Peel Extracts
}

\begin{abstract}
Abdulilah Saleh Ismaeil
Biology Department, Science College, Salahaddin University, Erbil, Erbil, Kurdistan Region, Iraq. E-mail: abdulillah1@yahoo.com
\end{abstract}

\section{Fraidoon Abdulqadr Salih}

Biology Department, Science College, Salahaddin University, Erbil, Erbil, Kurdistan Region, Iraq. E-mail: fraidoon.salih@su.edu.krd

\begin{abstract}
:
Pomegranate Peel extractions used as quorum sensing inhibitor (QSI) against Staphylococcus aureus (which isolated from soft white cheese in local market), different solvents used to obtain different active ingredient groups, minimum inhibitory concentration of each group were determined then sub-inhibitory concentration was used as (QSI). We get that all groups have ability to inhibit quorum sensing in Staphylococcus aureus in different ratio. By using Real-time PCR found that the different Pomegranate Peel extract groups can inhibit the expression of some quorum sensing and virulence factor genes ( Sea, Seb, AgrA, RNAIII, and Hla).

Also Pomegranate Peel extracts groups have a role in biofilm reduction in Staphylococcus aureus significantly, furthermore the extract groups significantly affect the growth curve of this bacteria. Our results idicated that the pomegranate peel extracts fight infections by supressing virulence factors, may be due to blocking autoinducer receptors.
\end{abstract}

Keywords: Staphylococcus Aureus, Pomegranate Peel Extract, Quorum Sensing Inhibitor, Biofilm, Growth Curve. 


\section{Introduction:}

Pomegranate (Punica granatum L. the name derived from ponus and granatus in Latin words), a granular or seeded apple. The pomegranate is native to Iran, China, Afghanistan and the Indian sub- continent. The ancient sources of pomegranate linked Pakistan to Iran, eastern India and China, where pomegranate shad been under cultivation for many of years (Celik et al., 2009, p.145). Pomegranate peel contains 26-30\% interior network of membranes of total fruit weight and are characterized by containing amounts of phenolic and flavonoid compounds (anthocyanins, catechins and other complex flavonoids) and hydrolysable tannins (pedunculagin, punicalin, ellagic acid, punicalagin and gallic). The mentioned compounds are seen in pomegranate peel (PoP) and juice, which account for $92 \%$ of the antioxidant activity associated with the fruit (Zahin et al., 2010, p.99). Gallic acid, ellagic acid and punicalagin, in addition to their scavenging of free radical properties, also possess antibacterial activity against microflora in intestine, especially enteric pathogens, i.e., Escherichia coli, Salmonella spp. Shigella spp., as well as Vibrio cholerae (Pai et al., 2011, p.57). Several projects have proved the antimicrobial, anti-helminthic, and antioxidant potential of (PoMx ), which is the active compounds of pomegranate peel extract, demonstrating the role of it in prevention and curation some diseases such as injury in gastrointestinal-mucosa, the chemoprevention of some type of cancer, ulcers and oxidative damage in diabetic patients (Arun \& Singh, 2012, p.1240).

A distinguished human pathogen Staphylococcus aureus which causes numerous infections (acute and chronic) such as pneumonia, pericarditis, and sepsis. This bacteria also produce food poisoning by secretion enterotoxins ( Chambers \& Deleo, 2009, p. 629). Quorum sensing (QS), an essential regulatory system of bacteria that depend on the production and detection of extracellular materials called autoinducers, have been shown to control virulence factors in many pathogens (Reuter et al., 2016, p.1). In S. aureus, the Agr (accessory gene regulator) QS is the prevalent and well-studied virulence regulator and is responsible for increased expression of virulence genes, inclusive many enzymes, and toxins that are critical for the infection establishment (Le \& Otto, 2015, p.1174). S. aureus express and secret virulence factors that responsible of bacterial pathogenicity is under control of (Agr) quorum -sensing system (Cheung et al., 2008, p.355). AgrA (response regulator) and AgrC (histidine kinase signal transduction) are components of (TCST) twocomponent signal transduction system of Agr system (Zehnpfennig et al., 2009, p.4423). In the external environment AIP (autoinducing peptide) activate and phosphorylate AgrC. The phosphate group transferred to AgrA, then the actived AgrA lead to virulence factor expression and formation of biofilm, this due to interaction between AgrA with RNAII and RNAIII (Matthew et al., 2011, p.117). The transautophosphorylation induced by $\mathrm{AgrC}$, which cause AgrA activation, this cause activation of $\mathrm{P} 2$ and $\mathrm{P} 3$ for RNAII and RNAIII respectively (George et al., 2009, p.44). The quorum sensing system Agr in staphylococci comprises of (2) components (RNAII and RNAIII) (Kavanaugh et al., 2007, p.780). Phosphorylated AgrA triggers The P2 and P3 promoter. is bound to the autoinducer the Agr operon by the phosphorylated AgrA. Besides triggering the P2 promoter. The expression of RNAIII is under control of the P3 promoter (Richard et al., 1993, p.3967). Production of $\alpha$-toxin is under control of RNAIII (Dunman et al., 2001, p.7341).

The use and Recognition of natural products have a long history. In the report of the World Health Organization (WHO), in developing countries around $80 \%$ of people confirm that the natural products have benefits for health nursing. Due to rising microorganisms resistance to ordinary drugs, the use and recognize 
of natural products were increased (Palombo, $2001 \&$ Mohapatra, 2011). The occurrence of MDR bacteria has motivated studies for weakening bacterial virulence differently through QS inhibition procedures instead of bactericidal and bacteriostatic strategies (Yang et al., 2015, p.18033). The present study is to using pomegranate peel extracts to attenuate $\mathrm{S}$. aureus pathogenicity.

\section{Materials and Methods}

\section{Isolation and identification Staphylococcus aureus from soft white cheese}

Staphylococcus aureus isolated and identified using FDA's Bacteriological Analytical Manual USA 2001(FDA, 2001)

\section{Pomegranate peel extractions}

Different solvents were used for the extraction of the active substances from pomegranate peel are selected primarily based on the polarity of the solute, from low polar to high polar, as follows: Hexane Chloroform - Ethylacetate - Butanol - Ethanol - Water (Altemimi et al., 2017, p.E42).

Weight $50 \mathrm{~g}$ of ground Pomegranate peel mixed with $100 \mathrm{ml}$ of Hexane put it in an ultrasonic bath (1.5 hours at $37^{\circ} \mathrm{C}$ ), then filtered the mixture we get extract part one (group 1) using rotary evaporator to evaporate hexane, the residue will be dried at room temperature and used for next solvent extraction.

The same technique used for the other solvents to get the extracts (group 2 from chloroform, group 3 from ethylacetate, group 4 from butanol, group 5 from ethanol, and group 6 from water) (Harborne, 1980).

\section{Determining minimum inhibitory concentration (MIC) of Pomegranate peel extracts:-}

96-well microplates (This method was beneficial in screening plants for anti-microbial activity and the bioassay-guided isolation of anti-microbial compound) was used to assay different concentrations of Pomegranate peel extracts $(0,2,4,5,10,15,20,25,50,75,100,125$ and $150 \mathrm{mg} / \mathrm{ml})$ by mixing with tryptone soy broth. All wells were inoculated with $10 \mu \mathrm{l}$ of the activated culture of Staphylococcus aureus, incubated overnight at $37{ }^{\circ} \mathrm{C}$ then the MIC was determined, all other tests was done by sub inhibitory concentrations (SIC) (Eloff, 1998, p.711).

\section{Enterotoxin detection assay by RPLA kit}

Staphylococcal enterotoxin test kit (RPLA kit) was used to for determining staphylococcal enterotoxins A, B, C, and D in culture supernatants (after growing bacteria in trypton soy broth which contain sub-mic Pomegranate peel extracts concentration) by passive agglutination (Sally \& Rose, 1989, p.65). 


\section{Determining gene expression by using real-time PCR}

Real-time PCR was used to know the effect of pomegranate peel extracts on expression each of (Sea, Seb, AgrA, RNAIII, and Hla gene), the total RNA extracted from the bacterial culture which growing in trypton soy broth contain sub-mic Pomegranate peel extracts comparing them with control culture of $S$. aureus.

The RNA was extracted by (Total RNA Purification Kit, Jena Bioscience-Germany) and used for real-time PCR (RT-PCR). cDNA was made from $1 \mathrm{~g}$ of RNA using high-capacity RNA-to-cDNA master mix (Applied Biosystems). For quantifiable real-time PCR, magnification was carried out with Power Syber green master mix in a step one plus thermal cycler (Applied Biosystems). The primers were obtained from other researchers. Thirty cycles were run with denaturation at $95^{\circ} \mathrm{C}$ for $15 \mathrm{~s}$, annealing at $55^{\circ} \mathrm{C}$ for the $30 \mathrm{~s}$, and extension at $60^{\circ} \mathrm{C}$ for $45 \mathrm{~s}$ (Jakobsen et al., 2012, p.2314).

Table 1.Oligonucleotide primers used for determining gene expression.

Primer Sequence Target Gene reference

Sea Fw GGTTATCAATGTGCGGGTGG Sea (Muyiwa, 2015, p.10254)

Sea Rv CGGCACTTTTTTCTCTTCGG

Seb Fw GTATGGTGGTGTAACTGAGC Seb (Muyiwa, 2015, p.10254)

Seb Rv CCAAATAGTGACGAGTTAGG

hla Fw ATGGTGAATCAAAATTGGGG hla

(Zhang et al., 2016, p.146)

hla Rv

GTTGTTTGGATGCTTTTC

RNAIII Fw AATACATAGCACTGAGTCCAAGG RNAIII (Da et al., 2017, p.257)

RNAIII Rv TGGATTATCGACACAGTGAACA

Agr A Fw

$$
\text { TGATAATCCTTATGAGGTGCTT }
$$

Agr A

( Da et al., 2017, p.257)

Agr A Rv CACTGTGACTCGTAACGAAAA 


\section{Effect of Pomegranate peel extracts on biofilm formation by $S$. aureus}

Microtiter plate method was used to detect biofilm formation in pomegranate peel extracts treated and untreated culture (O'Toole, 2011, p.2437).

\section{The effect of Pomegranate peel extracts on the growth curve of $S$. aureus}

The effect of Pomegranate peel extracts on the growth curve was determined by growing bacteria in a microtiter plate which contains trypton soy broth plus sub-mic pomegranate peel extracts, then measuring optical density in each hour in comparison with control culture (Zwietering et al., 1990, p.1875).

\section{Statistical Analysis}

One way anova and Duncan test used to compare between means.

\section{Results and discussion:}

From 31 isolates of Staphylococcus aureus, one isolates which is an enterotoxin A \& B producing strain (tested by RPLA-KIT) was chosen and different pomegranate peel groups were tested on it.

As shown in table 2 the mic of Pomegranate peel extract group 1, 2, 3, 4, 5, and 6 were 10, 20, 20, 10, 2, and $2 \mathrm{mg} / \mathrm{ml}$ respectively; the concentrations were different because the groups contain different active ingridents.

By RPLA test, we get that the all Pomegranate peel extract groups caused inhibition of enterotoxin expression as shown in table 3 .

By RT-PCR it was evident that the different Pomegranate peel extract groups have different effect on expression of tested gene (Sea, Seb, AgrA, RNAIII, and Hla), as shown in figure 1 group 3 of extracts supress all tested genes while group $4 \& 5$ let inhibited Sea and RNAIII respectivly also supressed other genes, group 1 has less effect than other groups.

Pomegranate peel extract caused decreasing biofilm formation by Staphylococcus aureus, according to one way ANOVA test $(\mathrm{P}<0.05)$, group $1,3,4$, and 5 decreased biofilm significantly while group 2 and 6 caused decreasing biofilm non significantly comparing with control, as shown in figure 2 .

Figures 3 and 4 showed the effect of Pomegranate peel extract on the growth curve of Staphylococcus aureus, as shown all extract groups have an effect on the growth curve, group 1, 4, and 5 significantly shortened the growth curve but group 2,3, and 6 have non-significant effect on growth curve, this results obtained by one way ANOVA test $(\mathrm{P}<0.05)$. 
It's clear in our results that the Pomegranate peel extract blocked some virulence factors and decreased the others, furthermore we note that the Pomegranate peel extract has a role in biofilm disassembly and changing Staphylococcus aureus behaviors.

The DNA microarray and quantitative real-time PCR (qRT-PCR) data studies had shown the decreasing expression of the QS regarding genes in several pathogenic bacteria, which lead to a reduction in their virulence properties (Harborne, 1980). Natural products from plants include favorable tools for the bacterial pathogenesis management and bacterial modulations. Previous studies on anti-QS activities or QSI of natural products in bacteria have concentrated mainly on elucidating the decreasing of expressions of well-established determine induced genes of QS (Mohapatra, 2011). The attenuation of bacterial virulence due to reduction of expression QS genes cause the prevention of bacterial pathogenicity (FDA, 2001). The reduction of expression QS genes and the level of signaling molecules that affect the production of virulence factors provide more insight into why these natural products were used in the past and how they can be used in the future to control the microbial infections (Eloff, 1998, p.65).

The mechanism of antimicrobial activity of phenolic compound groups include the reaction of phenolics with proteins in cell membrane of bacteria which cause bacterial death due to precipitation of membrane protein and enzyme inhibition for example glycosyltransferases (Naz et al., 2007, p.341). PoPx used for treating food-borne diseases and urinary tract infections in the Indian Subcontinent (El-Sherbini et al., 2010, p.229), while PoP ellagitannins, punicalagin, ellagic acid and gallic acid, as natural antimicrobial agents, have been widely used against $\mathrm{S}$. aureus and hemorrhagic E. coli for their ability to precipitate membrane protein and inhibit enzyme such asglycosyl transferases, leading to cell lysis (Naz et al., 2007, p.341 , Voravuthikunchai et al., 2005, p.590). In situ and in vivo applications of PoP 80\% methanolic extract showed an inhibitory effect against Listeria monocytogenes, S. aureus, E. coli and Yersinia enterocolitica (Al-Zoreky, 2009, p.244).

The studied plants' extracts at sub inhibitory concentrations also diminished biofilm development (especially hexane of OLE, butanol and ethanol fractions of pomegranate, the aqueous fraction of Quercus and ethyl acetate extract of the pomegranate peel) and the expression of QS and virulence genes without influencing the growth. Our findings on the inhibition of biofilms by plant extracts find support from (Hayat et al., 2017, p.325), Husain et al. (2015) who reported that plant extracts significantly inhibit the biofilm development in several pathogenic bacteria (Husain et al., 2015, p.420). Also Mohabi et al. (2017), who concluded the antibiofilm activity of $Q$. infectoria in $P$. aeruginosa (Mohabi et al., 2017, p.26). 


\section{تضميف البكتريا المنقودية بواسطة مستخلص قشرة الرمان}

قسم علوم الحياة، كلية العلوم، جامعة صلاح الدين، اربيل، اربيل، كردستان، العراق.

$$
\text { abdulillah1@yahoo.com }
$$

قسم علوم الحياة، كلية العلوم، جامعة صلاح الدين، اربيل، اربيل، كردستان، العراق. fraidoon.salih@su.edu.krd

\author{
مبادالأه صائج اسماعيل

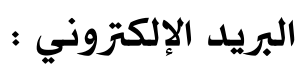

فربدوذ مبدالقادر مالح

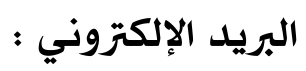

استخدمت مستخلص قشرة الرمان كمثبط استشعار النصاب (كورم سينسينك) ضد البكتريا العنقودية المعزولة من الجبن الابيض الطرى استخدمت المذيبات المختلفة للحصول على المواد الفعالة المختلفة وحددت التركيز الاقل تثبيطا لكل المجوعات و التزكيز قبل الزَكيز المثبط استخدمت كمثبط استشعار النصاب و بينت النتائج بان كل المتخلصات لها القدرة على تثبيط استشعار النصاب فى البكتزيا العنقودية بدرجات مختلفة ـ باستخدام تفاعل البوليميراز المتسلسل فى الوقت الحقيقى وجدت بان المستلخلصات قشرة الرمان المختلفة لها قدرة التثبيط بعض الجينات استشعار النصاب و عوامل الضراوة مثل Sea, Seb, AgrA, RNAIII, and Hla

كما بينت بان مستخلصات قشرة الرمان لها القدرة على اختزال الغشاء الحيوى بشكل معنوى فى الكتريا العنقودية بالاضافة الى ان المستلصات قشرة الرمان يؤثر معنويا على المنحنى النمو لهذا البكتريا.حسب ما وصلنا اليه فى النتائج اتضحت بان مستلص قشرة الرمان يحلد الاصابة عن طريق تقليل عوامل الضراوة و من الممكن ان يكون ذلك عن طريق غلق المستقبلات فى جدار الخلية البكتيرية.

كلمات الداللة؛ البكتريا العنقودية , مستخلص قشرة الرمان , مثبط استشعار النصابي , الغشاء الحيوي , منحنى النمو. 


\section{References:}

ALTEMIMI A, LAKHSSASSI N, BAHARLOUEI A, WATSON DG, LIGHTFOOT DA. Phytochemicals: Extraction, Isolation, and Identification of Bioactive Compounds from Plant Extracts. Plants (Basel). 2017;6(4).

AL-ZOREKY N S. Antimicrobial activity of pomegranate (Punica granatum L.) fruit peels.International Journal of Food Microbiology.2009;134,244-248.

ARUN N. \& SINGH D. P. Punica granatum: a review on pharmacological and therapeutic properties.International Journal of Pharmaceutical Sciences and Research.2012;3(5),12401245.

CELIK,I.,TEMUR,A.,ISIK,I...Hepato protective role and antioxidant capacity of pomegranate (Punicagranatum) flowers infusion against trichloro acetic acid- exposed in rats.Food and Chemical Toxicology: An International Journal Published for the British Industrial Biological Research Association. 2009;47,145-149.

CHAMBERS HF, DELEO FR. Waves of resistance: Staphylococcus aureus in the antibiotic era. Nat Rev Microbiol. 2009;7(9):629-41.

CHEUNG AL, NISHINA KA, TROTONDA MP, TAMBER S. The SarA protein family of Staphylococcus aureus. Int J Biochem Cell Biol. 2008;40(3):355-61.

DA F, YAO L, SU Z, HOU Z, LI Z, XUE X, et al. Antisense locked nucleic acids targeting agrA inhibit quorum sensing and pathogenesis of community-associated methicillin-resistant Staphylococcus aureus. Journal of applied microbiology. 2017;122(1):257-67.

DUNMAN PM, MURPHY E, HANEY S, PALACIOS D, TUCKER-KELLOGG G, WU S, et al. Transcription profiling-based identification of Staphylococcus aureus genes regulated by the agr and/or sarA loci. Journal of bacteriology. 2001;183(24):7341-53. 
ELOFF JN. A sensitive and quick microplate method to determine the minimal inhibitory concentration of plant extracts for bacteria. Planta medica. 1998;64(8):711-3.

\section{EL-SHERBINI G M, IBRAHIM K M, EL SHERBINY E T, ABDEL-HADY N M, MORSY T A .} Efficacy of Punica granatum extract on in-vitro and in-vivo control of Trichomonas vaginalis. Journal of the Egyptian Society of Parasitology.2010;40, 229-244

FDA. Bacteriological Analytical Manual. 2001.

GEORGE CISAR EA, GEISINGER E, MUIR TW, NOVICK RP. Symmetric signalling within asymmetric dimers of the Staphylococcus aureus receptor histidine kinase AgrC. Mol Microbiol. 2009;74(1):44-57.

HARBORNE JB. PHYTOCHEMICAL METHODS. CHAPMAN AND HALL,London EC4P 4EE. 1980.

HAYAT S, SABRI A N, MCHUGH T D. Chloroform Extract of Turmeric Inhibits Biofilm Formation, Eps Production and Motility in Antibiotic Resistant Bacteria. The Journal of General and Applied Microbiology, 2017;63, 325-338.

HUSAIN F M, AHMAD I, KHAN M S, AHMAD E, TAHSEEN Q, KHAN M S, ALSHABIB N A. Sub-Mics of Mentha Piperita Essential Oil and Menthol Inhibits Ahl Mediated Quorum Sensing and Biofilm of Gram-Negative Bacteria. Frontiers in Microbiology,2015;6, 420.

JAKOBSEN TH, VAN GENNIP M, PHIPPS RK, SHANMUGHAM MS, CHRISTENSEN LD, ALHEDE M, et al. Ajoene, a sulfur-rich molecule from garlic, inhibits genes controlled by quorum sensing. Antimicrobial agents and chemotherapy. 2012;56(5):2314-25.

KAVANAUGH JS, THOENDEL M, HORSWILL AR. A role for type I signal peptidase in Staphylococcus aureus quorum sensing. Mol Microbiol. 2007;65(3):780-98.

LE KY, OTTO M. Quorum-sensing regulation in staphylococci-an overview. Frontiers in microbiology. 2015;6:1174.

MATTHEW THOENDEL JSK, CARALYN E. FLACK, AND ALEXANDER R. HORSWILL. Peptide Signaling in the Staphylococci. Chem Rev. 2011;111:117-51. 
MOHABI S, DAVOOD KALANTAR-NEYESTANAKI, MANSOURI S. Inhibition of Quorum Sensing-Controlled Virulence Factor Production in Pseudomonas aeruginosa by Quercus infectoria Gall Extracts. Iranian journal of Microbiology,2017;9 26-32.

MOHAPATRA DP, THAKUR V, BRAR SK. Antibacterial efficacy of raw and processed honey. Biotechnol Res Int. 2011;2011:917505.

MUYIWA AJOKE AKINDOLIRE OOBACNA. Detection of Antibiotic Resistant Staphylococcus aureus from Milk: A Public Health Implication. International Journal of Environmental Research and Public Health. 2015;12.

M. H. ZWIETERING IJ, F. M. ROMBOUTS, AND K. VAN 'T RIET. Modeling of the Bacterial Growth Curve. Applied and environmental microbiology. 1990;56(6):1875-81.

NAZ S, SIDDIQI R, AHMAD S, RASOOL S A, SAYEED S A . Antibacterial activity directed isolation of compounds from Punica granatum. Journal of Food Science.2007;72, M341-345.

O'TOOLE GA. Microtiter dish biofilm formation assay. Journal of visualized experiments : JoVE. 2011(47).

PAI V, CHANU T R, CHAKRABORTY R., RAJU B., LOBO R., BALLAL M ..Evaluation of the antimicrobial activity of Punica granatum peel against the enteric pathogens: an invitro study.Asian Journal of Plant Science and Research1.2011; (2), 57-62.

PALOMBO EA. Traditional Medicinal Plant Extracts and Natural Products with Activity against Oral Bacteria: Potential Application in the Prevention and Treatment of Oral Diseases. Evid Based Complement Alternat Med. 2011;2011:680354.

REUTER K, STEINBACH A, HELMS V. Interfering with Bacterial Quorum Sensing. Perspect Medicin Chem. 2016;8:1-15.

RICHARD P.NOVICK HFR, STEVEN J.PROJAN JK, MOGHAZEH BKAS. Synthesis of staphylococcal virulence factors is controlled by a regulatory RNA molecule. The EMBO Journal. 1993;12(10):3967-75. 
SALLY A.\& ROSE PBAMFS. Detection of staphylococcal enterotoxins in dairy products by the reversed passive latex agglutination (SET-RPLA) kit International Journal ofFoodMicrobiology. 1989;8:65-72.

VORAVUTHIKUNCHAI S P, SRIRIRAK T, LIMSUWAN S, SUPAWITA T, IIDA T, HONDA T .

Inhibitory effects of active compounds from Punica granatum pericarp on Verocytotoxin by enetrohaemorrhagic Escherichia coli 0157: H7.Journal of Health Science.2005;51,590-596.

YANG Q, SCHEIE AA, BENNECHE T, DEFOIRDT T. Specific Quorum Sensing Disrupting Activity (a QSI) of Thiophenones and Their Therapeutic Potential. Scientific Reports,2015; 5, 18033.

ZHANG H, ZHENG Y, GAO H, XU P, WANG M, LI A, et al. Identification and Characterization of Staphylococcus aureus Strains with an Incomplete Hemolytic Phenotype. Frontiers in cellular and infection microbiology. 2016;6:146.

ZAHIN, M., AQIL,F., AHMAD,I...Broad spectrum antimutagenic activity of antioxidant active fraction of Punica granatum L. pee lextracts.Mutation Research.2010;703,99-107.

ZEHNPFENNIG B, URBATSCH IL, GALLA HJ. Functional reconstitution of human ABCC3 into proteoliposomes reveals a transport mechanism with positive cooperativity. Biochemistry. 2009;48(20):4423-30. 